\title{
Internalization of Character Education in Civic Education Learning Based on Multiple Intelligence
}

\author{
Fera Amalia Rabbani ${ }^{1, *}$, Muhammad Halimi
}

\author{
1,2 Universitas Pendidikan Indonesia, Bandung, Indonesia \\ *Corresponding author. Email: feraarabbani@upi.edu
}

\begin{abstract}
This study aims to understand the concept of multiple intelligence-based learning that defines that different intelligences having by each individual, multiple intelligences itself is seen by researchers as possible in the application of character education because it has the characteristics of autonomy which each child is seen as unique and they have advantages and strengths in a particular field, understanding it is expected that character education through Civic Education learning based on multiple inteligences is able to better penetrate into the child. The research focuses on the values of character that can be built and developed through the internalization of character education in Civic Education learning based on multiple intellegences. This research was conducted by Content Analysis method to obtain information from communication, by examining various documents related to relevant studies from journals, textbooks and learning tools
\end{abstract}

Keywords: Character Education, Multiple Intellegences, Uniqueness of Students.

\section{INTRODUCTION}

In the description related to the concept, purpose, and function of Indonesian national education contained in the law of the education system No. 20 of 2003 emphasizes that Indonesian national education is very concerned about the three aspects of ability, cognitive, affective, and psychomotor. Character that is part of the affective and psychomotor aspects also takes precedence over achievement in national education. The government also pays more attention by prioritizing the formation of character that can be seen from the development of the nation's character making it as a mainstream in national development. Engaging students through activities, identification and excavation of intelligence, as well as promoting diversity of tendencies, interests, talents, talents, must be an integral part of learning. Thus the learning process involving teacher activities, student activities, media, and learning resources will be able to accommodate and facilitate the growth and development of plural intelligence owned by students.

\section{THEORETICAL REVIEW}

Friedrich William Foerster, a German pedagog and originator of character education, argued that the purpose of education was to form a character manifested in the essential unity between a person and his behavior and attitude ( Koesoema, 2007) .[1]
Character development in schools must be done systematically and continuously. Character formation must be done systematically and continuously involving aspects of knowledge, felling, loving, and action (Muchlish, 2011). [2] Further character is developed through the stage of knowing, acting, towards habit (Zainal, 2011).[3] This means that the character is not limited to knowledge. A person who has knowledge of goodness is not necessarily able to act according to his knowledge if he is not trained to do that good. Rather, it should be continued with efforts to foster a sense of loving good behavior and do every day as habituation.

Howard Gardner is the inventor of the Theory of Multiple Intelligences, calling it that there are 9 (nine) different intelligences possessed by each individual, not all intelligence stands out in the individual but there is at least one intelligence that stands out in the individual's personality. These nine intelligences we will look deeper in the next paragraph. Thus if an information or rule from outside is presented in accordance with one of the intelligence that stands out in a person, then he will easily and quickly respond and be able to absorb the information or rules well.

Multiple Intelligences has a method of discovering ability (Gardner. H, 2011) [4] meaning the process of finding a person's ability. This method believes that everyone must have a certain type of intelligence tendencies. Such tendencies must be discovered through intelligence searches. Engaging students through activities, identification and excavation of 
intelligence, as well as promoting diversity of tendencies, interests, talents, talents, must be an integral part of learning. Thus the learning process involving teacher activities, student activities, media, and learning resources will be able to accommodate and facilitate the growth and development of plural intelligence owned by students.

\section{METHOD}

The method used in this study is a qualitative method with a research procedure that generates discrete data (data collected in the form of words, images, and not numbers). While the type of research that researchers use is Content Analysis by examining data documentation in the form of text, images, symbols, and so on. Research by Content Analysis method is used to obtain information from communication, which is delivered in the form of documented or documentable symbols. This method can be used to analyze all forms of communication, such as newspapers, books, movies and so on. By using the Method of Content Analysis, it will be obtained an understanding of the various contents of communication messages that are conveyed by the mass media, or from other sources objectively, systematically, and relevantly.

\section{RESULTS AND DISCUSSION}

Multiple Intelligences developed by Howard Gardner is based on the understanding that one learns by utilizing different types of intelligence (Hailey, 2014).[5] This means that individual learning varies across parts of human potential where individual differences stem from bio-psychological and cultural factors affecting skills and even abilities.

Multiple Intelligences between specialized theoretical intelligences include a diversity of individual characteristics, and lead to a more effective and sensible approach to addressing each student's uniqueness in the classroom. The implications for educators and students are tremendous in terms of the wealth and flexibility of Multiple Intelligences in teaching and learning activities. As educators develop and utilize pedagogy consciously try to engage students in a variety of ways, knowing the intelligence students have is essential for effective instruction. This provides double the benefits of this evaluation. If teachers know the strengths of their students, then they will be able to better prepare interesting and relevant lessons related to that strength. Second, students know their strengths, so they can engage in various strategies to improve their learning accordingly (Griggs, L, etc.,2009). [6]

Multiple Intelligences, provides a new lens that will be used to view and address the problems that plagued educators, students, and schools for decades.
"Traditional IQ tests, developed in the 1900s, deal mainly with logic/math and language intelligence. The test is not designed to measure other types of intelligence that people have" (Kezar, 2001). [7] However, Multiple Intelligences provides improvements to this by allowing it to recognize different abilities and abilities of people in general. This means that schools are actually able to expand their curriculum and develop better assessments, which can be applied to future lives. The emergence of Emotional Intelligences (EI) has also supported a new understanding of Multiple Intelligences. Thus supporting new insights into intelligence impacting Gardner's Multiple Intelligences (MI) theory became more resilient, as the idea of "emotion" made possible, even relative and subjectivity in definitions that truly constitute intelligence. In addition, it has made social and interpersonal interactions more developed, as it is considered an important skill as a spectrum of human abilities, and it helps to formulate understanding as a factor that influences the uniqueness of the individual.

Civic Education is truly one of the subjects rich in character values. Civic Education is one of the leading sectors of character learning. Therefore, the character objectives set out in Civic Education learning are actually instructional impacts that want to be achieved not just limited to the impact of companion. However, in the current reality Civic Education seems to be a subject that is not considered so important because Civic Education lessons are limited to material memorizing activities and are less able to perform their functions as leading sectors of character education. At the learning planning stage, all that must be done is to prepare the syllabus and lesson plan. Therefore, in this study I conducted an analysis of the syllabus and lesson plan prepared by teachers in porting Civic Education learning character in the classroom (Puspa Dianti, 2014). [8].

Planning on the learning outlined in the lesson plan has a great function in making character education successful in learning. There are two functions of lesson plan in making character education successful in schools, namely:

1. Planning function. In the implementation of character education in schools, lesson plan serves to encourage every teacher to be better prepared in conducting learning activities, forming competencies, and character of learners with careful planning.

2. Implementation function. To succeed the implementation of character education in schools lesson plan must be prepared systematically and systematically, intact and thoroughly, with several possible adjustments in the actual learning situation. In this case, the standard material developed and used as study material by students must be adapted to the conditions and needs of the 
environment, schools, and regions (Mulyasan, 2013). [9]

Lesson plan according to Munif Chatib is the planning made by teachers before teaching. In general, a Lesson Plan there is a learning strategy (Munif,2012) [10] In a learning strategy, there are two patterns of cooperation, namely teachers teaching (presentation) and students learning (activities). A good learning strategy is a learning strategy that can invite students to learn. Learning strategies that can invite students to learn, often referred to as studentfocused learning strategies. To be able to develop student-focused learning strategies, teachers must be aware of the student's initial condition. This initial condition can be used as a consideration to arouse the attention of students. One way to raise students' attention is that teachers must master the theory of aperception.

According to Herbart, the frequency of the human brain, has four waves, namely alpha $(7-13 \mathrm{~Hz})$, beta $(13-25 \mathrm{~Hz})$, delta $(0.5-3.5 \mathrm{~Hz})$, teta $(3.5-7 \mathrm{~Hz})$. The best wave to start the learning process is alpha wave, because in alpha waves the human brain is in a comfortable but focused condition. It is this wave that is best suited for aperception. Thus, a good aperception is to direct the student's brain to enter into the alpha zone. To enter the alpha zone there is a special stimulus that must be done by teachers, namely by doing ice breaking, fun story, music, and brain gym(Munif,2012). [10].

The above two things are an important component in the creation of lesson plan, which must be known by the teacher. However, to develop a Lesson Plan is also required framework or systematic Lesson Plan. There have been many experts who make systematic Lesson Plan based on the theories of learning they follow.

Chatib, trying to design the Lesson Plan systematics creatively. Systematic Creative Lesson Plan referred to as follows (a) header or opener, which contains identity and syllabus, (b) content or content, consisting of, aperception (alpha zone, warmer, pretech, and scene setting), teaching strategy, activity procedure, teaching aids, learning resources, project, (c) footer or cover, consisting of rubric assessment and teacher comments. Teacher comments can be problems, new ideas, and special moments. The activity procedure is a learning activity that will be conducted by students. So that in the activity procedure there are various activities of students during the learning process in one meeting. Thus the activeness or absence of students depends on the activity procedures that have been planned by the teacher. Activity procedures can involve students' intelligence (Munif,2012).[11]

The activity procedure involving several areas of student intelligence in accordance with the theory of Multiple Intelligences is called the Multiple
Intelligences approach. In this study, Lesson Plan that uses Multiple Intelligences approach is referred to as Multiple Intelligences-based Lesson Plan. Thus it can be concluded that the Lesson Plan based on Multiple Intelligences is a learning plan that is prepared by involving all the intelligence possessed by students while following the planned learning process. The implementation of Lesson Plan based on Multiple Intelligences will be supported by other learning tools, namely Student Worksheets whose stages are adjusted to the learning stages in lesson plan.

Furthermore, another thing that can be seen from the character syllabus prepared by the teacher, the researchers see that the teacher has not made any modifications in the assessment technique component because on the syllabus there are no additions / modifications to the assessment technique component. For this component teachers have tried to choose the form of written test assessment and observation of the attitude of students. However, the form of written assessment given by the teacher is only limited to the practices of the problem that according to the researchers are only able to see the cognitive abilities of students only, while for observation of attitudes the teacher only performs itself and involves less of the active role of the student. For example, by inviting students to do self-assessment or can also use a form of assessment between friends. Therefore, researchers feel that teachers are still not maximal in making modifications to the syllabus on the components of learning activities and assessment techniques. Teachers should make more changes and creativity at that stage because both components are an important part that must be modified to support character learning. This is in accordance with the guidelines for the implementation of the syllabus of the Character of the Ministry of Education that to facilitate the occurrence of learning that helps learners develop character needs to be done:

a. Addition and/or modification of learning activities so that it contains learning activities that are able to develop the desired character values.

b. Addition and/or modification of assessment techniques so that there are assessment techniques that can develop and/or measure character development (Gunawan, 2021) [14].

\section{CONCLUSION}

Research by Content Analysis method is used to obtain information from various references, books. and research collected by the authors. The importance of modern teaching design is required to design educational materials faster, and use fast and diverse ways and methods of delivery and learning strategies. Of course, in order for character education to be effective, it takes continuity and cooperation from the 
family as well, especially parents. It is undeniable that the earliest and most effective character education is by example the people closest to the child. Character is a process of heart formation, not cognitive, so it needs a real example in everyday life. Therefore, character education conducted by the school needs to be continued and affirmed by those closest to the child in their daily lives.

The integration of character education in civic education is a solution that can revive the role of civic education as a subject that is the leading sector in the development of student character. civic education is a civic education subject that in its material content is already rich in character values will be more helpful with the integration of the concept of character education. Student character development is not only developed through the content of Civic Education material, but the character of students can be developed indirectly through stages in learning activities, furthermore it can be supported by the use of methods, media, and learning resources.

\section{REFERENCES}

[1] Koesoema, Doni, Pendidikan Karakter. Jakarta:Grasindo, 2007.

[2 ].Masnur, Muchlish, Pendidikan Karakter Menjawab Tantangan Krisis Multidimensional. Jakarta : Bumi Aksara, 2011.

[3] Aqib, Zainal dan Sujak, Panduan dan Aplikasi Pendidikan Karakter. Jakarta : Gaung Persada Press, 2011.

[4] Gardner. H, Frames of Mind: The theory of Multiple Intelligences. New York, NY: Basic Books, 2011.

[5] Haley, M.H. "Learner-Centered Introduction and the Theory of Multiple Intelligences with Second Language Learners'. Teachers College Record. Volume 106, No. 106. No.1, pp 163-180, 2014.

[6] Griggs, L., Barney. S., Brown-Sederberg ., Collins, E., Keith , S., \& Ianacci, L., "Varying pedagogy to address student Multiple Intlligence". Human Architecture. 7 (1). pp 5560, 2009.

[7] Kezar, A. "Theory of Multiple Intelligences : Implications for Higher Education". Journal Innovative Higher Education. 26 (2). (p. 141 154). Doi: 10.1023/A: 1012292522528, 2001.

[8] Puspa Dianti, "Integration of Character Education in Civics Education Learning To Develop Student Character". JPIS, Jurnal Pendidikan Ilmu Sosial, Volume 23, No. 1, Edition Juny, pp.58-68, 2014.

[9] Mulyasa. Manajemen Pendidikan Karakter. Jakarta: Bumi Aksara, 2013.
[10] Munif Chatib \& Alamsyah Said, Gurunya Manusia, Bandung: Kaifa, 2012. 